\title{
Multi-use of the sea: from research to practice
}

Joanna Przedrzymirska ${ }^{1}$, Jacek Zaucha ${ }^{1}$, Daniel Depellgrin ${ }^{2}$, Rhona Fairgrieve ${ }^{3}$, Andronikos Kafas ${ }^{3}$, Helena Maria Gregório Pina Calado ${ }^{4}$, Marta Horta de Sousa Vergílio ${ }^{5}$, Mario Cana Varona ${ }^{6}$, Marija Lazić ${ }^{2}$, Angela SchultzZehden $^{7}$, Ivana Lukic ${ }^{7}$, Eva Papaioannou ${ }^{8}$, Martina Bocci ${ }^{9}$, Rianne Läkamp ${ }^{10}$, Ioannis.Giannelos ${ }^{10}$, Aneta Kovacheva $^{10}$, and Bella Buck ${ }^{11}$

${ }^{1}$ The Maritime Institute in Gdansk, Długi Targ 41/42, 80-830 Gdańsk, Poland

${ }^{2}$ CNR - National Research Council of Italy, ISMAR - Institute of Marine Sciences Arsenale - Tesa 104, Castello 2737/F, I30122 Venice, Italy

${ }^{3}$ Marine Scotland Science, 375 Victoria Road, Aberdeen, AB11 9DB, Scotland, UK

${ }^{4} \mathrm{MARE}$ - Marine and Environmental Sciences Centre; FCT - University of the Azores, 9501-801 Ponta Delgada, Azores, Portugal.

${ }^{5} \mathrm{CIBIO}$ - Research Centre in Biodiversity and Genetic Resources/InBIO - Associate Laboratory; University of the Azores, 9501-801 Ponta Delgada, Azores, Portugal.

${ }^{6}$ University of the Azores, 9501-801 Ponta Delgada, Azores, Portugal.

${ }^{7}$ SUBMARINER Network for Blue Growth EEIG, Kärntener Str. 20, DE-10827 Berlin, Germany

${ }^{8}$ University of Dundee, Nethergate, Dundee DD1 4HN, United Kingdom

${ }^{9}$ Thetis SpA, Castello 2737/f, 30122 Venice, Italy

${ }^{10}$ Ecorys Nederland, Watermanweg 44, 3067 GG Rotterdam, The Netherlands

${ }^{11}$ Am Handelshafen 12, 27570 Bremerhaven, Germany

\begin{abstract}
The increasing demand for ocean resources exerts an increasing pressure on the use of ocean space across all European Sea Basins. This underlines issues of compatibility (or conflicts) between different maritime uses as well as between economic activities and environmental protection. The idea of multi-use (MU), as a guiding concept for efficient allocation of compatible activities in the same marine space, can increase spatial efficiency and at the same time provide socio-economic and environmental benefits. However, its transition from a concept to real-world development is facing several barriers. Based on analysis of five European sea basins done under the Horizon 2020 MUSES project (Multi-Use in European Seas), this paper aims to clarify the concept of MU by discussing: 1) the definition in the literature and practice so far, and; 2) how existing regulatory and planning regimes are supporting and challenging the development of several MUs (considered as the most promising). The analytical methodology developed for the MUSES project relied on data collected via desk research and semi structured interviews with key stakeholders (e.g. industry, regulators), over the period of seven months. The semi-quantitative analysis of data conducted, identified the commonalities and differences among countries in respect to each of the analyzed MUs. The paper points out priorities for the MU development in different sea basins and recommends initial steps to overcome existing barriers, whilst maximizing local benefits. This paper is a starting point towards a broader scientific debate on: (i) what could be the role of management policies (like for instance maritime spatial planning - MSP) in supporting and fostering MU concept development, (ii) what are technical and technological challenges for technically advanced MUs, (iii) how added values of MUs concept (e.g. benefits for local economies, positive impacts on environment) could be enhanced.
\end{abstract}

\section{Acknowledgement}

Analyses presented in this paper were financed by the European Union's Horizon 2020 research and innovation programme under Grant Agreement no 727451. The authors would like to thank the MUSES project consortium and all project partners for their valuable contributions to the project. The MUSES project is funded by the EU Framework Programme for Research and Innovation Horizon 2020. Grant number: 727451. More information can be found at https://muses-project.eu/. 


\section{Introduction}

Multi-use (MU) at the sea is a relatively new research topic that has emerged from three distinctive sources. The first one is research and innovation, that prompts out development of new technologies offering novel ways of exploitation of sea resources and improvement of its conservation measures. Several research projects [1] have been conducted e.g. to investigate the possibility of establishing multi-purpose off-shore platforms, serving needs of off-shore energy production, mariculture or sea tourism and even regular navigation. Some combinations have been researched even more extensively such as off-shore wind energy and aquaculture and substantial documentation exists in this field (e.g. [2], [3]). The second source is business itself, e.g. tourism in the Mediterranean region considering new opportunities such as pescatourism [4] or underwater culture heritage. This provides possibilities for combinations such as tourism and fishery or tourism and protection of underwater artifacts. The third source is scarcity of space. The emergence of maritime spatial planning [5-13] made it evident that marine space is not abundant and it should be treated as a scarce resource [14]. Therefore, MSP urges for sparing use of the sea space [15] and $\mathrm{MU}$ is among the considered solutions. Some scholars see MU as an analogue to the economies of scales that drive terrestrial spatial development[16].

\section{The essence of Multi-Use}

The discussions and developments of MU of marine resources in the political and academic arena have generated a variety of terms to describe the context. Each nomenclature is trying to capture and convey important information about the particularities of their investigated scenario. As a result many differing terms have emerged during the last 15 years for the same concept idea: co- and translocation, multi- and multi-functional use, co-use, secondary and additional use and coexistence to name a few.

The information conveyed by these terms can cover every dimension from legal and business relationships of users to even temporal and physical aspects of the multi-use relationship.

According to a definition elaborated within the MUSES project, 'multi use' (MU) is considered as a "joint use of resources in close geographic proximity". The term is an umbrella term covering a multitude of use combinations in the marine realm and representing a radical change from the concept of exclusive resource rights to the inclusive sharing of resources by one or more users. This can involve either a single user or multiple users. The use means distinct and intentional activity through which a direct (e.g. profit) or indirect (e.g. nature conservation) benefit is drawn by one or more users. The user means individual, entity or group that intentionally benefits from a given resource, and the resource is understood as a good or service that represents a value to one or more users (e.g. biotic, such as fish stocks; or abiotic, such as ocean space) and can be exploited through either direct (e.g. fishing) or indirect (e.g. nature conservation) uses [1].

It is often difficult to differentiate between genuine MU and the mere coexistence of several uses. For example, ships and fish use the same seawaters. However, this should not be considered as a MU, even though the condition of lack of exclusivity is fulfilled. It's doubtful whether this joint use of resources is intentional (rather than coincidental) and is beneficial to both parties. Also diving in wreck sites should not be considered as a MU. However, diving in the intentionally prepared and maintained underwater sanctuaries is considered as a $\mathrm{MU}$, because it is based on conscious decisions and provides benefits to both users.

Recognizing the multitude of possible multi-use scenarios in European seas, two essential types of MUs are defined:

a) Multi-use of geographical, human, biological resources

b) Multi-use of technical resources (marine infrastructure \& platforms)

The first type means that multi-use of marine resources refers mainly to the geographical connection of resource uses to create benefits for society and single actors. An example of such a multi-use is the combination of offshore wind and tourism through boat tours viewing the offshore wind farm [17].

The second type means even closer (functionally and geographically) integration of uses to create even more added value than a side-by-side scenario. This closer integration looks for synergies in integrating the operations and implementation of offshore activities and can start by e.g. the simple sharing of the use of offshore supply vessels to reduce individual operations costs. The synergistic integration of activities culminates in multi-use platforms. MU offshore platforms are engineering solutions, designed to incorporate modules of other compatible activities (e.g. TROPOS Project). A fully integrated multi-component and multi-purpose offshore platform serves as a main 
infrastructure shared by two or more ocean uses (e.g. H2Ocean project designed a platform coupling renewable energy harvesting + hydrogen generation + aquaculture + environmental monitoring)[18].

In terms of sequence in which the development occurs, two scenarios of MU creation are considered as presented in Figure 1.

\section{Joint development of uses}

MU where two (or more) combined uses (from the blue growth sector i.e. aquaculture or offshore wind) are applying for licenses at the same time

\section{Staggered development of uses}

VS

One existing (traditional) use is already

in place and the new (emerging) one is coming in MU where one sector is already in place (e.g. underwater heritage protection) and is being combined with the new use (e.g. tourism)

Fig. 1. Two possible scenarios for the sequence of multi-use developments. Source: own elaboration SUBMARINER and AWI

\section{Multi Use as research subject}

Several types of MU combinations have been researched in a wide variety of possible MU combinations, all of them at different stages of their maturity and feasibility. The list of combinations (Tab.1) was compiled after identifying combinations that have been analysed by past projects. A total of 26 case studies analysed in past projects (e.g. MARIBE, MERMAID, H2Ocean and TROPOS) have resulted in 11 uses considered as MU.

Table 1. MU combinations identified in the international projects

\begin{tabular}{|c|c|c|}
\hline Project & Use & Co-Uses \\
\hline \multicolumn{3}{|c|}{ EU funded projects } \\
\hline $\begin{array}{l}\text { COEXIST } \\
\text { Project ID } 245178\end{array}$ & $\begin{array}{l}\text { Fisheries and } \\
\text { aquaculture }\end{array}$ & Other coastal activities (stakeholder) \\
\hline $\begin{array}{l}\text { H2Ocean } \\
\text { Project ID } 288145\end{array}$ & Wind and Wave energy & $\begin{array}{l}\text { Aquaculture, } \\
\text { Hydrogen (stored and shipped to shore as green energy } \\
\text { carrier) }\end{array}$ \\
\hline \multirow{2}{*}{$\begin{array}{l}\text { MARIBE } \\
\text { (Marine Investment for the Blue Economy - } \\
\text { Baltic, North Sea, Atlantic, Caribbean, } \\
\text { Mediterranean) } \\
\text { Project ID } 652629 \\
\text { (collected results from all other finished EU } \\
\text { multi-use projects) }\end{array}$} & Caribbean: Aquaculture & $\begin{array}{l}\text { Tourism, } \\
\text { Wave energy, } \\
\text { Desalination }\end{array}$ \\
\hline & $\begin{array}{l}\text { Mediterranean: } \\
\text { Aquaculture }\end{array}$ & Tourism \\
\hline \multirow{4}{*}{$\begin{array}{l}\text { MERMAID } \\
\text { (Baltic, North Sea, Atlantic Mediterranean, } \\
\text { Lead: DTU) } \\
\text { Project ID } 288710\end{array}$} & $\begin{array}{l}\text { Atlantic: Offshore wind } \\
\text { and wave energy }\end{array}$ & Maritime transport, \\
\hline & $\begin{array}{l}\text { Mediterranean: Wave } \\
\text { energy }\end{array}$ & $\begin{array}{l}\text { Leisure, } \\
\text { Aquaculture, } \\
\text { Maritime transportation }\end{array}$ \\
\hline & North Sea: Wind energy & $\begin{array}{l}\text { Aquaculture (seaweed and shellfish), } \\
\text { Tourism }\end{array}$ \\
\hline & Baltic: Wind farm & $\begin{array}{l}\text { Passive Fisheries, } \\
\text { Aquaculture (fish and seaweed) }\end{array}$ \\
\hline $\begin{array}{l}\text { ORECCA (Offshore Renewable Energy } \\
\text { Conversion platforms - Coordination Action) } \\
\text { Project ID } 241421\end{array}$ & Offshore Renewables & $\begin{array}{l}\text { Aquaculture (biomass and fish), } \\
\text { Monitoring of the sea environment (marine mammals, } \\
\text { fish and bird life) }\end{array}$ \\
\hline $\begin{array}{l}\text { TROPOS (Mediterranean, Tropic, Sub-tropic, } \\
\text { Lead: PLOCAN) } \\
\text { Project ID } 288192\end{array}$ & $\begin{array}{l}\text { Maritime transport } \\
\text { (offshore port and base }\end{array}$ & $\begin{array}{l}\text { Fisheries (service station, storage), } \\
\text { Aquaculture (fish), } \\
\text { Energy (solar and ocean wave), }\end{array}$ \\
\hline
\end{tabular}




\begin{tabular}{|c|c|c|}
\hline & $\begin{array}{l}\text { of logistic service for } \\
\text { energy sector) }\end{array}$ & $\begin{array}{l}\text { Leisure activities (floating hotel, underwater observation } \\
\text { facility, scientific tourism, diving base, yachting services) }\end{array}$ \\
\hline $\begin{array}{l}\text { MARINA Platform } \\
\text { Project ID } 241402\end{array}$ & Wind Energy & Wave Energy \\
\hline \multicolumn{3}{|c|}{ National funded projects } \\
\hline Project & Use & Co-Use \\
\hline $\begin{array}{l}\text { AquaLast } \\
\text { (Germany - Lead: AWI; University of Applied } \\
\text { Sciences Bremerhaven, Fraunhofer, } \\
\text { Weswerwind, TKB) } \\
\text { (AWI) }\end{array}$ & Offshore Wind Energy & $\begin{array}{l}\text { Aquaculture } \\
\text { (loading on offshore support structures, such as wind } \\
\text { turbine foundations, caused by mussel longlines) }\end{array}$ \\
\hline $\begin{array}{l}\text { Biological and technical feasibility study of } \\
\text { marine aquaculture in the Thorthonbank } \\
\text { area, Belgium: Co-use of space with offshore } \\
\text { wind farms } \\
\text { (Belgium - University of Ghent, SINTEF } \\
\text { Ocean) }\end{array}$ & Offshore Wind Energy & $\begin{array}{l}\text { Aquaculture } \\
\text { (farming of blue mussel ) }\end{array}$ \\
\hline $\begin{array}{l}\text { Coastal Futures } \\
\text { (Germany - Lead: University of Kiel; AWI, } \\
\text { GKSS) } \\
\text { (AWI) }\end{array}$ & Offshore Wind Energy & $\begin{array}{l}\text { Aquaculture } \\
\text { (integrated coastal zone management for the integration } \\
\text { of aquaculture into wind farm areas) }\end{array}$ \\
\hline $\begin{array}{l}\text { Flandres Queen Mussel (FIOV) } \\
\text { (Belgium - Stichting voor Duurzame } \\
\text { Visserijontwikkeling -SDVO, ILVO) }\end{array}$ & Offshore Wind Energy & $\begin{array}{l}\text { Aquaculture } \\
\text { (development of floating buoys with mussel ropes for spat } \\
\text { collection) }\end{array}$ \\
\hline $\begin{array}{l}\text { Gulf of Mexico OOA } \\
\text { (USA - University of Texas) }\end{array}$ & Offshore Oil Platforms & $\begin{array}{l}\text { Aquaculture } \\
\text { (multi-use of offshore fish cultivation in combination with } \\
\text { offshore Oil \& Gas) }\end{array}$ \\
\hline $\begin{array}{l}\text { Integrate the offshore wind technology with } \\
\text { aquaculture - development of fish farm } \\
\text { equipment for offshore conditions } \\
\text { (Norway - Statoil, SINTEF Ocean and Lerøy } \\
\text { Seafood Group) }\end{array}$ & Offshore Wind Energy & $\begin{array}{l}\text { Aquaculture } \\
\text { (fish farming of salmon) }\end{array}$ \\
\hline $\begin{array}{l}\text { KOREA Co-Location } \\
\text { (South Korea - Lead: Korea Electric Power } \\
\text { Cooperation Research Institute (KEPCO); } \\
\text { Korean Institute of Ocean Science and } \\
\text { Technology - KIOST) }\end{array}$ & Offshore Wind Energy & $\begin{array}{l}\text { Fisheries (passive fisheries), } \\
\text { Aquaculture } \\
\text { (seaweed production for biomethane and bioproducts in } \\
\text { wind farms) }\end{array}$ \\
\hline $\begin{array}{l}\text { Mosselkweek in Belgische windmolenparken } \\
\text { - Mussel production within Belgium Wind } \\
\text { Farms } \\
\text { (Belgium - Lead: University of Ghent; ILVO, } \\
\text { AWI, SINTEF, et al.) }\end{array}$ & Aquaculture & $\begin{array}{l}\text { Wind energy, } \\
\text { Maritime energy }\end{array}$ \\
\hline $\begin{array}{l}\text { MytiFit } \\
\text { (Germany - Lead: AWI; Engel Netze, LAVES) } \\
\text { (AWI) }\end{array}$ & Offshore Wind Energy & $\begin{array}{l}\text { Aquaculture } \\
\text { (mussel fitness, infestation of parasites, and selection of } \\
\text { hard substrates for multi-use) }\end{array}$ \\
\hline $\begin{array}{l}\text { NutriMat } \\
\text { (Germany - Lead: IMARE; Greim Fish } \\
\text { Consulting, AWI, University of Applied } \\
\text { Science Bremerhaven, WeserWind, Louis } \\
\text { Schoppenhauer GmbH \& Co. KG) }\end{array}$ & Offshore Wind Energy & $\begin{array}{l}\text { Aquaculture } \\
\text { (use of fouling organisms of offshore platforms for fish } \\
\text { feed in land-based aquaculture) }\end{array}$ \\
\hline $\begin{array}{l}\text { Nysted Sea Wind Farm Mussels } \\
\text { (Belgium - DTU) }\end{array}$ & Offshore Wind Energy & $\begin{array}{l}\text { Aquaculture } \\
\text { (investigation on the possibility to multi-use for longline } \\
\text { mussel farming) }\end{array}$ \\
\hline $\begin{array}{l}\text { Ocean Forest } \\
\text { (Norway - Leroy Seafood Group, Bellona } \\
\text { Foundation) }\end{array}$ & $\begin{array}{l}\text { Aquaculture (multi- } \\
\text { trophic) } \\
\text { Energy }\end{array}$ & Aquaculture (bio-mass production for energy generation) \\
\hline $\begin{array}{l}\text { Offshore-Aquaculture } \\
\text { (Germany - Lead: AWI; Terramare) }\end{array}$ & Offshore Wind Energy & $\begin{array}{l}\text { Aquaculture } \\
\text { (investigations of the settlement and growth of bivalves } \\
\text { and macroalgae in the German Bight to test its feasibility } \\
\text { for offshore multi-use) }\end{array}$ \\
\hline $\begin{array}{l}\text { Offshore Site } \\
\text { Selection } \\
\text { (Germany - Lead: AWI; Thünen, University of } \\
\text { Rostock, Kutterfisch, WindMW, Deutscher } \\
\text { Fischereiverband, Skretting) }\end{array}$ & Offshore Wind Energy & $\begin{array}{l}\text { Aquaculture } \\
\text { (offshore site selection for IMTA in co-use of offshore } \\
\text { wind farms) }\end{array}$ \\
\hline $\begin{array}{l}\text { Open Ocean Use (OOMU) } \\
\text { (Germany - Lead: IMARE; EWE, University of } \\
\text { Hannover, Thünen Institute, Bard Engineering, } \\
\text { Kutterfisch, Frosta, AWI) }\end{array}$ & Offshore Wind Energy & $\begin{array}{l}\text { Aquaculture } \\
\text { (investigation on integrating an offshore fish cage into } \\
\text { tripile foundation) }\end{array}$ \\
\hline $\begin{array}{l}\text { Roter Sand Project } \\
\text { (Germany - Lead: AWI) }\end{array}$ & Offshore Wind Energy & $\begin{array}{l}\text { Aquaculture } \\
\text { (development of system design for the use of offshore } \\
\text { environments for the cultivation of species for } \\
\text { aquaculture and bioextraction) }\end{array}$ \\
\hline
\end{tabular}




\begin{tabular}{|l|l|l|}
\hline $\begin{array}{l}\text { SOMOS - Safe production Of Marine plants } \\
\text { and use of Ocean Space } \\
\text { (The Netherlands - Lead: Wageningen } \\
\text { University; TNO) }\end{array}$ & $\begin{array}{l}\text { Offshore Renewable } \\
\text { Energy }\end{array}$ & $\begin{array}{l}\text { Aquaculture } \\
\text { (Seaweed farming) }\end{array}$ \\
\hline $\begin{array}{l}\text { Stichting Noordzeeboerderij } \\
\text { (The Netherlands - Hortimare, Schuttelaar and } \\
\text { Partners) }\end{array}$ & Offshore Wind Energy & $\begin{array}{l}\text { Aquaculture } \\
\text { (development of a seaweed technology and mass algal } \\
\text { production) }\end{array}$ \\
\hline $\begin{array}{l}\text { WINSEAFUEL } \\
\text { (France - French National Research Agency) }\end{array}$ & Offshore Wind Energy & $\begin{array}{l}\text { Aquaculture } \\
\text { (seaweed mass production for biomethane and } \\
\text { bioproducts in wind farms) }\end{array}$ \\
\hline
\end{tabular}

Source: own elaboration by SUBMARINER and AWI

Figure 2. illustrates that combinations may differ in terms of their potential/feasibility and time of appearance. Some of them are very probable in the near future, some may be possible in several years' time, and others are not likely to occur at all. However, this matrix is indicative of the complexity of the MU research.

\begin{tabular}{|c|c|c|c|c|c|c|c|c|c|c|c|}
\hline & 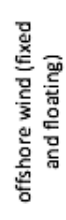 & 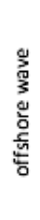 & 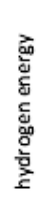 & 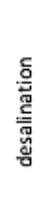 & 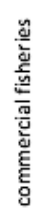 & 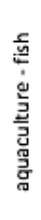 & 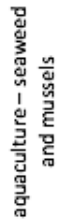 & 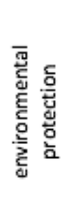 & 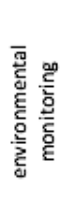 & 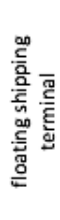 & 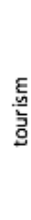 \\
\hline $\begin{array}{l}\text { offshore wind (fix } \\
\text { and floating) }\end{array}$ & & & & & & & & & & & \\
\hline offshore wave & & & & & & & & & & & \\
\hline hydrogen energy & & & & & & & & & & & \\
\hline desalination & & & & & & & & & & & \\
\hline commercial fishe & & & & & & & & & & & \\
\hline aquaculture - fish & & & & & & & & & & & \\
\hline $\begin{array}{l}\text { aquaculture - } \\
\text { seaweed and mu }\end{array}$ & & & & & & & & & & & \\
\hline $\begin{array}{l}\text { environmental } \\
\text { protection }\end{array}$ & & & & & & & & & & & \\
\hline $\begin{array}{l}\text { environmental } \\
\text { monitoring }\end{array}$ & & & & & & & & & & & \\
\hline $\begin{array}{l}\text { floating shipping } \\
\text { terminal }\end{array}$ & & & & & & & & & & & \\
\hline tourism & & & & & & & & & & & \\
\hline
\end{tabular}

Legend:

\section{MU possible}

\section{MU somewhat feasible in the near future}

Mu not possible in the near future

Fig. 2. Feasibility of multi-uses combining two uses. Source: own elaboration by AWI and SUBMARINER

\section{The researched sea basins}


It is evident that MUs might differ in the EU sea basins due to their specific features facilitating development of some uses and hindering others. Five distinctive sea basins are defined in the EU sea waters if the outermost regions are not included: the North-Eastern Atlantic (EA), the North Sea (NS), the Baltic Sea (BSR), the Mediterranean Sea (Med) and the Black Sea (BS) (Fig 3). Each of these sea basins is characterized by different physical conditions resulting in different uses of sea resources. However, despite obvious differences, several common trends important for MU development are observed: 1) sectors dominating in the given sea basin seem to strongly influence development of MU, 2) environmental assets tend to have a more important role in allocation of the sea space to particular uses, 3) local and regional economic development is a driving force for local MU initiatives.

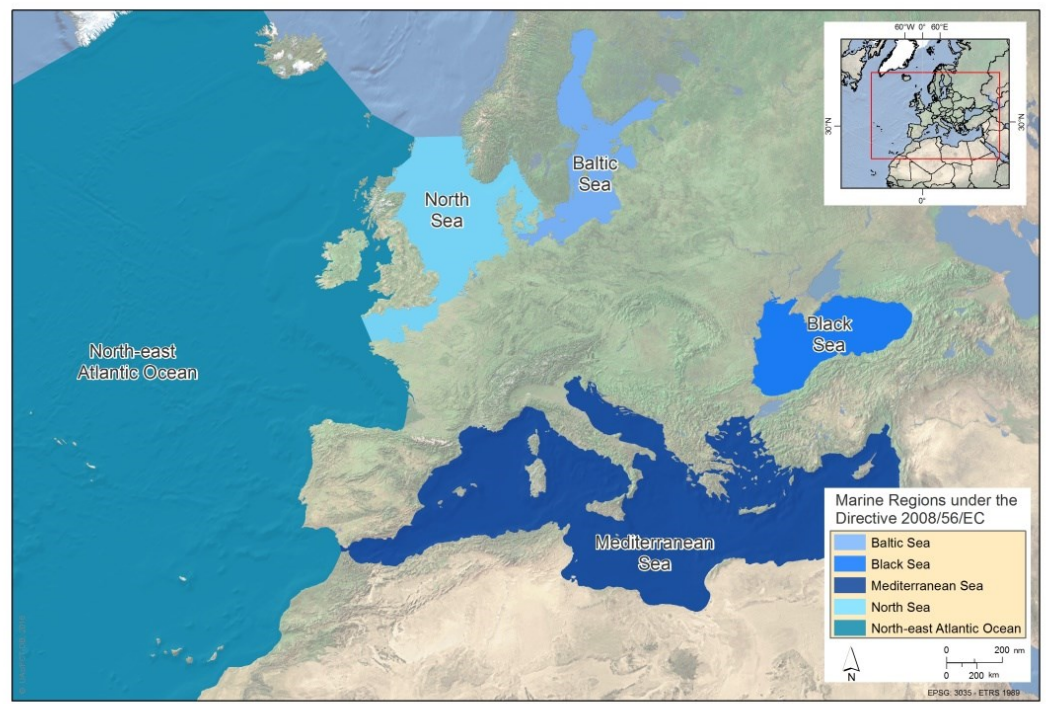

Fig. 3. Sea basins analysed under MUSES project (drawing on [1])

A brief comparison between sea basins is provided in Table 2. Evidence is clear that some physical conditions (wind potential) support multi-use based on wind farms in the North Sea and Eastern Atlantic, whereas high temperature signifies an importance of tourism and possibility to combine tourism with other activities in the Black Sea and Mediterranean Sea. Low salinity hinders mussels aquaculture in the Black Sea and the Baltic.

Table 2. Overview of prevailing physical conditions in the analysed sea basins

\begin{tabular}{|c|c|c|c|c|c|c|c|c|c|}
\hline \multirow{2}{*}{$\begin{array}{l}\text { Sea } \\
\text { Basi } \\
n\end{array}$} & \multirow[t]{2}{*}{ EU Countries involved } & \multirow{2}{*}{$\begin{array}{l}\text { Area } \\
{\left[\mathrm{km}^{2}\right]}\end{array}$} & \multicolumn{6}{|c|}{ Physical characteristics } & \multirow[t]{2}{*}{ Notes } \\
\hline & & & $\begin{array}{l}\text { Win } \\
\text { d }\end{array}$ & Waves & Tides & $\begin{array}{l}\text { Temperature } \\
{\left[{ }^{\circ} \mathrm{C}\right]}\end{array}$ & $\begin{array}{l}\text { Salinit } \\
\mathrm{y} \\
{[\mathrm{psu}]}\end{array}$ & $\begin{array}{l}\text { Dept } \\
\mathrm{h} \\
{[\mathrm{m}]}\end{array}$ & \\
\hline$\overline{\mathrm{EA}}$ & $\begin{array}{ll}\text { Portugal (PT), } & \text { Spain } \\
\text { (ES), France (FR), } \\
\text { Ireland (IR), United } \\
\text { Kingdom (UK) }\end{array}$ & $?$ & $\begin{array}{l}\text { Exce } \\
\text { llent }\end{array}$ & Powerful & Strong & $\begin{array}{l}\text { Surface: } \\
\text { between } 7 \text { and } \\
15 \\
\text { Deep waters: } \\
\text { between } 5.5 \\
\text { and } 7.5\end{array}$ & $\begin{array}{l}35 \text { or } \\
\text { higher }\end{array}$ & $\begin{array}{l}5000 \\
\text { (ocea } \\
\text { n) }\end{array}$ & $\begin{array}{l}\text { Part of the world ocean. EU } \\
\text { countries have jurisdiction } \\
\text { over large maritime spaces. }\end{array}$ \\
\hline NS & $\begin{array}{lr}\text { Denmark } & \text { (DK), } \\
\text { Germany } & (\mathrm{DE}) \\
\text { Belgium (BE), France } \\
(\text { FR), United Kingdom } \\
(\mathrm{UK}), \quad \text { Netherlands } \\
(\mathrm{NL}),\end{array}$ & $\begin{array}{l}570,00 \\
0\end{array}$ & $\begin{array}{l}\text { Exce } \\
\text { llent }\end{array}$ & $\begin{array}{l}\text { Strong (in } \\
\text { comparison } \\
\text { to the open } \\
\text { ocean } \\
\text { smaller } \\
\text { speed and } \\
\text { the larger } \\
\text { amplitude) }\end{array}$ & Strong & $\begin{array}{l}\text { Average: } 17 \\
\text { in the summer } \\
\text { and } 6 \text { in the } \\
\text { winter }\end{array}$ & $\begin{array}{ll}25 & - \\
34.5 & \end{array}$ & $\begin{array}{l}\text { avera } \\
\text { ge } \\
90\end{array}$ & $\begin{array}{l}\text { Partially enclosed by land } \\
\text { but directly connected with } \\
\text { Atlantic Ocean, intensively } \\
\text { used for various economic } \\
\text { sectors. }\end{array}$ \\
\hline$\overline{B S R}$ & $\begin{array}{lr}\text { Germany } & \text { (DE), } \\
\text { Denmark } & \text { (DK), } \\
\text { Sweden (SE), Finland }\end{array}$ & $\begin{array}{l}415,26 \\
6\end{array}$ & $\begin{array}{l}\text { Goo } \\
\text { d }\end{array}$ & Moderate & Weak & $\begin{array}{ll}\text { Surface: } & \\
\text { between } & -0.5 \\
\text { to } & +20 \\
\end{array}$ & $\begin{array}{l}18 \\
\text { (west) } \\
-\quad 0 \\
\end{array}$ & $\begin{array}{l}\text { avera } \\
\text { ge } 54\end{array}$ & $\begin{array}{l}\text { Completely enclosed by } \\
\text { land, connected with the } \\
\text { North Sea through Danish }\end{array}$ \\
\hline
\end{tabular}




\begin{tabular}{|c|c|c|c|c|c|c|c|c|c|}
\hline & $\begin{array}{l}\text { (FI), Estonia (EE), } \\
\text { Lithuania (LT), Latvia } \\
(\mathrm{LV}), \text { Poland (PL) }\end{array}$ & & & & & $\begin{array}{l}\text { depending on } \\
\text { the season }\end{array}$ & $\begin{array}{l}\text { (north- } \\
\text { eastern } \\
\text { ) }\end{array}$ & & $\begin{array}{l}\text { straights, intensively used } \\
\text { for shipping and fishery. }\end{array}$ \\
\hline $\begin{array}{l}\mathrm{ME} \\
\mathrm{D}\end{array}$ & 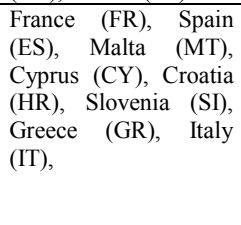 & $\begin{array}{l}2,505 \\
000\end{array}$ & $\begin{array}{l}\text { Mod } \\
\text { erate } \\
\text { and } \\
\text { good }\end{array}$ & Varies & Weak & $\begin{array}{l}\text { Surface: } 21- \\
28 \text { in the } \\
\text { summer, } 10- \\
17 \text { in the } \\
\text { winter }\end{array}$ & $\begin{array}{ll}36.5 \quad- \\
39\end{array}$ & $?$ & $\begin{array}{l}\text { Completely enclosed by } \\
\text { land, connected with the } \\
\text { Atlantic Ocean through the } \\
\text { Strait of Gibraltar, } \\
\text { intensively used for } \\
\text { shipping, tourism and } \\
\text { fishery with growing } \\
\text { importance of aquaculture. }\end{array}$ \\
\hline BS & $\begin{array}{ll}\text { Romania } & (\mathrm{RO}), \\
\text { Bulgaria }(\mathrm{BY}) & \end{array}$ & $\begin{array}{l}436,00 \\
0\end{array}$ & $\begin{array}{l}\text { Mod } \\
\text { erate }\end{array}$ & Moderate & Weak & $\begin{array}{l}\text { Summer: up } \\
\text { to } 30 \text { (surface } \\
\text { ) and } 8.5 \\
\text { (deep waters) }\end{array}$ & $17-18$ & $\begin{array}{l}\text { Aver } \\
\text { age } \\
1253\end{array}$ & $\begin{array}{l}\text { Completely enclosed by } \\
\text { land, connected with the } \\
\text { Mediterranean Sea through } \\
\text { the Dardanelles and the } \\
\text { Bosporus, intensively used } \\
\text { for shipping, tourism and } \\
\text { fishery. }\end{array}$ \\
\hline
\end{tabular}

Source: own elaboration by MIG

Availability of space is also a relevant factor influencing the development of MU. In small sea areas where space is scarce, MU might be seen as an opportunity to use space in a more efficient way. In the oceans and other deep sea areas, MU might be driven mainly by the economic benefits of such an approach (e.g. offshore MU platforms) rather than spatial efficiency.

\section{The most relevant multi-use combinations for each sea basin}

Analyses were conducted at three geographical scales:

- $\quad$ Scale 1 - Intra-country scale: within single country;

- Scale 2 - Basin/sub-basin scale: sum of findings from all countries within a basin or sub-basin;

- Scale 3 - Trans-boundary scale: two or more countries.

The analyses were conducted with the use of various research methods including desk-based review of relevant regulations (international to local levels), project reports and case studies, scientific reports, workshops and interviews with stakeholders associated with marine planning in general and MU in particular. Relevant data was collected at country-level and results aggregated and analysed at sea basin level.

The stakeholders' preferences for individual MUs were revealed in the course of in depth interviews. The stakeholders' opinions were confronted with the previous desk research findings and related to the sectoral experience with MU development and to some extent also with the policy will in promotion of MU. As the result, the combinations were prioritised taking into account that at least one sector has been already existent (and preferably demonstrated some MU experience) and some policy will was in place (e.g. for tourism, fishery and aquaculture in the Mediterranean sea basin). The top three combinations per sea basin are presented in Table 3.

Altogether, in all five sea basins, $14 \mathrm{MU}$ combinations have been identified as existing or having potential. Six of them have been selected as the most relevant in the sea basins at least in one of the sea basins (Table 3).

Table3. The most relevant MUs selected in the sea basins analysis

Note: blue number indicates the number of countries within the sea basin in which the given MU exists, orange number indicates the number of countries in which the given MU has potential as one use is already in place.

\begin{tabular}{|l|l|l|l|l|l|l|}
\hline & MU name & EA & NS & BSR & MED & BS \\
\hline MU1 & Offshore Wind and Aquaculture & $1 / 2$ & $3 / 1$ & $1 / 3$ & $1 / 1$ & - \\
\hline MU2 & Offshore Wind and Tourism & $1 / 1$ & 1 & $3 / 2$ & - & - \\
\hline MU3 & Offshore Wind and Fisheries & 1 & 4 & 1 & - & - \\
\hline MU4 & Aquaculture and Tourism & $3 / 1$ & - & 1 & $3 / 3$ & 2 \\
\hline MU5 & Fisheries and Tourism and Environmental Protection & 3 & - & 1 & $5 / 3$ & 2 \\
\hline MU6 & $\begin{array}{l}\text { Underwater Cultural Heritage and Tourism and Environmental } \\
\text { Protection }\end{array}$ & 3 & - & $4 / 2$ & $1 / 4$ & 2 \\
\hline
\end{tabular}

Source: own elaboration by Maritime Institute in Gdańsk 
Out of eight in-depth analysed MUs, the most frequent (in terms of appearance as the existing in EU countries, see table 3) have been the three related to tourism (MU2, MU4 \& MU6). The combination of Fisheries and Tourism and Environmental Protection has been tested or established in ten countries and within three sea basins in which tourism is a driving force for blue growth. Also, the combination of Underwater Cultural Heritage and Tourism and Environmental Protection has often occurred (ten countries) in four out of five sea basins. The third most frequent MU is Aquaculture and Tourism - existing (according to the MUSES categorisation)| in six member states of Southern Europe located in the Mediterranean and East Atlantic sea basins. Thus, in the policy supporting MU, tourism as a MU driver should be properly considered. The fourth MU in terms of practical deployment is Offshore Wind and Aquaculture, that has been tested or exists in six countries (though in some cases energy is mainly a supplement to existing aquaculture with no ambition to produce energy for sale).

However, in terms of future development, the picture looks quite different. The biggest expectations are formulated by stakeholders towards Offshore Wind and Aquaculture as well as Underwater Cultural Heritage and Tourism and Environmental Protection. Both MU combinations exist or have development potential (with one use already in place) in 13 and 16 countries respectively. Both of these MU combinations have been prioritised in four sea basins, however the first type of MU is not so prominent for the Black Sea and the second one for the North Sea basin. This can be explained at least partially by physical characteristics of these sea basins and their policy specificities in terms of blue growth. Wind energy is not a priority in the Black Sea whereas in the North Sea underwater cultural heritage is not regarded as a development driver (i.e. the following sectors take a lead in blue economy: commercial fisheries, oil and gas production, shipping and maritime transport, tourism and offshore renewable energy development).

\section{Conclusions for further research}

Selection of the most important MUs for each sea basin seems only a top of an iceberg. There is a need for further research in order to make the MU concept operational. To summarize the findings from this paper, the following topics need further detailed research:

1. Researching MU in the context of resilience of marine ecosystems, since so far the economic and planning perspective prevails in researching MU.

2. Establish the economic value of different combinations which might be challenging due to important externalities related to them. Such research can change opinions of stakeholders and give space for new priorities in relation to MU deployment.

3. Better understanding of stakeholders' opinions with regard to MU. For instance in the Mediterranean sea basin, combinations related to tourism were prioritised as the most relevant due to their prevalence and importance for almost all countries in the given sea basin. Whereas combinations related to offshore wind scored high due to high probability of France to increase investment in multitrophic aquaculture combined with floating wind turbines that might offer EU breakthrough for this MU. Those peculiarities deserve more in depth analysis.

4. Analysing possible deployment paths of the most promising MUs in the sea basins, in particular the combinations related to offshore energy and tourism as driving sectors. The assistance should be tailored to the maturity level of the supported combinations and the size of barriers hindering their development. Also sea basin specificities must be taken into consideration. The support must be adjusted to the macro regional needs. Casting support for MU development requires prior understanding of the reasons behind prioritisation of some uses by macro regional experts.

All of the aspects mentioned above call for further research. In order to support the MU approach in a conscious way - i.e. to move from research to practice - a different approach seems necessary. Previous research has been focusing on the technical aspects of MU deployment. To complement this research, the social aspects need to be further investigated, using behavioral economics, business anthropology and other fields of social science. Applied research covering stakeholders' motivations and attitudes, describing drivers and barriers and identifying feasible policy solutions is essential for successful MU deployment in the future. 


\section{References}

1. J. Zaucha, M. Bocci, D. Depellegrin, I. Lukic, B. Buck, M. Schupp, M. Caña Varona, B. Buchanan, A. Kovacheva, P.K. Karachle, et al. (2017) Analytical Framework (AF) - Analysing Multi-Use (MU) in the European Sea Basins. Edinburgh: MUSES project

2. T. Michler-Cieluch, G. Krause, B. H. Buck (2009) Reflections on integrating operation and maintenance activities of offshore wind farms and mariculture. Ocean \& Coastal Management 52(1): 57-68

3. B. H. Buck, R. Langan (eds.) (2017)Aquaculture Perspective of Multi-Use Sites in the Open Ocean. The Untapped Potential for Marine Resources in the Anthropocene. Springer International Publishing, $404 \mathrm{p}$

4. W. Piasecki, Z. Głąbiński, P. Francour, P. Koper, G. Saba, A. Molina García, V. Únal, P.K. Karachle, A. Lepetit, R. Tservenis, Z. Kızılkaya, K.I. Stergiou (2016). Pescatourism-A European review and perspective. Acta Ichthyol. Piscat. 46 (4): 325-350.

5. A. Schultz-Zehden, K. Gee, K. Scibior (2008). Handbook on Integrated Maritime Spatial Planning. Berlin: S.PRO, 98 p.

6. F. Douvere, C.N. Ehler (2009). New perspectives on sea use management: Initial findings from European experience with marine spatial planning. Journal of Environmental Management, 90(1): 77-88

7. H. Calado, K. Ng, D. Johnson, L. Sousa, M. Phillips, F. Alves (2010). Marine spatial planning: Lessons learned from the Portuguese debate. Marine Policy, 34: 1341-49

8. Jay S., Flannery W., Vince J., Liu W.-H., Xue J.G., Matczak M., Zaucha J., Janssen H., van Tatenhove J., Toonen H., Morf A., Olsen E., Suárez de Vivero J.L., Rodríguez Mateos J.C., Calado H., Duff J., Dean H. (2013). Coastal and marine spatial planning. W: Chircop A., Coffen-Smout S., McConnell M. (red.). Ocean Yearbook. Leiden: Brill (Ocean Yearbook; 27): 171-212

9. J. Zaucha (2014a). The Key to governing the fragile Baltic Sea. Maritime Spatial Planning in the Baltic Sea Region and Way Forward. Riga: VASAB, $110 \mathrm{p}$.

10. J. Zaucha (2014b). Sea basin maritime spatial planning: A case study of the Baltic Sea region and Poland. Marine Policy, 50: 34-45

11. A. Barbanti, P. Campostrini, F. Musco, A. Sarretta, E. Gissi (red.) (2015). Developing a Maritime Spatial Plan for the Adriatic-Ionian Region. Venice: CNR-ISMAR, $255 \mathrm{p}$.

12. W. Flannery, G. Ellis, M. Nursey-Bray, J.P. van Tatenhove, C. Kelly, S. Coffen-Smout, R. Fairgrieve, M. Knol, S. Jentoft, (2016). Exploring the winners and losers of marine environmental governance/Marine spatial planning: Cui bono?/“More than fishy business": epistemology, integration and conflict in marine spatial planning/Marine spatial planning: power and scaping/Surely not all planning is evil?/Marine spatial planning: a Canadian perspective/Maritime spatial planning - "ad utilitatem omnium"/Marine spatial planning: "it is better to be on the train than being hit by it"/Reflections from the perspective of recreational anglers... Planning Theory and Practice, 17: 121-151

13. A. Schultz-Zehden, K. Gee, (2016). Towards a multi-level governance framework for MSP in the Baltic. Bulletin of the Maritime Institute in Gdańsk, 31(1): 34-44

14. J. Zaucha, (2009). Planowanie przestrzenne obszarów morskich. Polskie uwarunkowania i plan pilotażowy. Gdańsk: Instytut Morski w Gdańsku, 149 p.

15. K. Gee, A. Kannen, B. Heinrichs (2011). BaltSeaPlan Vision 2030: Towards the sustainable planning of Baltic sea space. Hamburg: BaltSeaPlan, $46 \mathrm{~s}$.

16. J. Zaucha (2018) Gospodarowanie przestrzenią morską. Warszawa: Wydawnictwo naukowe Sedno

17. V. Westerberg, J. Bredahl Jacobsen, R. Lifran, 2013. The case for offshore wind farms, artificial reefs and sustainable tourism in the French mediterranean. Tourism Management 34: 172-183. doi.org/10.1016/j.tourman.2012.04.008.

18. M. Stuiver, K. Som, P. Koundouri , S. van den Burg, A. Gerritsen, T. Harkamp, N. Dalsgaard, F. Zagonari, R. Guanche, J-J Schouten, S. Hommes, A. Giannouli, T. Söderqvist, L. Rosen, R. Garção, J. Norrman, C. Röckmann, M. de Bel, B. Zanuttigh, O. Petersen, F. Møhlenberg (2016). The Governance of multi-use platforms at sea for energy production and aquaculture: challenges for policy makers in European seas. Sustainability 8(4):333. doi: 10.3390/su804033

19. S. Davoudi, J. Zaucha, Brooks E. (2016). Evolutionary resilience and complex lagoon systems Integrated Environmental Assessment AND Management, 12(4): 711-8 